\title{
Five Reasons for Confidence in China's Economic Future
}

\author{
Samantha Zhu
}

\begin{abstract}
Globalization and digital disruption have reshaped the world trade order and industrial landscape - a process that has put China at the center. The five reasons China will remain a leader in the global economy in the near future include its "dual circulation" strategy, domestic demand-driven growth, digital technologies, carbon neutrality, as well as entrepreneurship and innovation. While there are uncertainties in the world, China is well placed to continue to be a major leader in the world economy.
\end{abstract}

Keywords Leader in the global economy • "dual circulation" strategy • Domestic demand-driven growth $\cdot$ Digital technologies $\cdot$ Carbon neutrality $•$

Entrepreneurship

The first two decades of the twenty-first century have ushered in extraordinary, complicated changes that have left many astounded. Globalization and digital disruption have reshaped the world trade order and industrial landscape-a process that has put China at the center. However, future historians might say the twenty-first century actually started in the year 2021.

As a major global event, the coronavirus pandemic has profoundly changed the course of the global economy. The post-pandemic era is expected to hold great potential for China's development. The country is in the process of shifting its economic development model from one that emphasizes high volume growth, scale and acrossthe-board development to one that prioritizes quality growth, efficiency and structural optimization. Such changes are boosting the likelihood that China will emerge as the world's largest economy in the coming decade. Business leaders believe China will make significant near-term strides. According to the Accenture CXO Pulse Survey, $70 \%$ of Chinese executives are optimistic that there will be a V-shaped rebound in China's economy in the coming year, compared with $37 \%$ and $27 \%$ of North American and European executives, respectively. Additionally, over $40 \%$ of senior

\footnotetext{
S. Zhu $(\varangle)$

Accenture Greater China, Beijing, China 
executives in the West view their region as less competitive than China was prior to the COVID-19 outbreak. $^{1}$

Of course, there are many unknowns ahead. And there are sure to be daunting challenges and difficulties. There always are. Yet, we are confident in China's future for the following five reasons.

\section{The "Dual Circulation" Strategy: Opening More to the Outside World}

History has taught us that an open society keeps developing while a closed one regresses. Under its "dual circulation" strategy — which is focused on both global and domestic markets and driven by the new round of technological innovation-China has the potential to evolve from a producer of quantity to a producer of quality.

China's development has reached a critical point where opening itself to the outside world and going global are equally important. According to the latest Investment Trends Monitor by UNCTAD, foreign direct investment (FDI) in China rose by $4 \%$ in 2020 to USD163 billion, making the country the world's largest FDI recipient. ${ }^{2}$

New agreements are helping to ensure that China will retain its global stature. The Regional Comprehensive Economic Partnership (RCEP), which was signed in 2020, is the largest and most important free trade agreement in the Asia-Pacific region, covering nearly half of the world's population and approximately a third of the world's trade volume. Its Asia-Pacific members will all benefit from being part of such a huge international trading bloc. For example, the RCEP will help significantly reduce transaction costs and improve efficiency. It will also serve as a new driver for job creation among member countries.

Additionally, negotiations for the EU-China Comprehensive Agreement on Investment (CAI) have been completed as scheduled. The CAI will bring greater market access for bilateral investments between China and the EU, as well as an enhanced business environment and stronger institutional support for these investments. As a result, prospects for cooperation between China and the EU are promising. Such agreements, which further open up China to the world, are key to the country's long-term prosperity and development.

Improving international trade relations is, however, just one element of China's growth strategy. Accenture research suggests that innovation will be even more critical. New technologies, for example, will unleash human potential, accelerate the implementation of innovation projects, and further facilitate international trade and cooperation. A forecast model developed by Accenture shows that by 2030, technological innovations have the potential to unlock USD 1.9 trillion worth of value above and beyond the anticipated USD 26.2 trillion of GDP expected in that year. In

\footnotetext{
${ }^{1} 1$ Accenture CEO Survey, All respondents $(\mathrm{N}=4050)$, North America $(\mathrm{N}=1450)$, Europe $(\mathrm{N}=$ 1301), China $(\mathrm{N}=320)$.

${ }^{2}$ https://unctad.org/system/files/official-document/diaeiainf2021d1_en.pdf.
} 
other words, by 2030, technical innovations will be directly responsible for or $7.5 \%$ of China's GDP. ${ }^{3}$

\section{Domestic Demand-Driven Growth: Focusing Reforms on Both Supply and Demand Sides Create a Healthy and Dynamic Balance}

As China's economy keeps growing and technologies continue to evolve, some existing industries will gradually decline and new ones will emerge. It is imperative that structural reforms of the supply side be enacted. Now that China has industrialized its primary and intermediary sectors, the focus will turn to high-tech industries, including 5G, clean energy automobiles, intelligent manufacturing new materials, and other areas. These industries are poised to lead the revitalization of China's industrial value chain and supply chain.

While carrying out its industrial upgrades, China will also need to stimulate consumption, hence, its focus on domestic demand. Morgan Stanley predicts the country's private consumption is likely to reach USD 12.7 trillion by 2030 . This means Chinese private consumption will likely grow by about $7.9 \%$ a year in the next decade, representing one of the highest growth rates in the world. ${ }^{4}$ Chinese consumers aren't just consuming more, they are starting to consume differently. Moving forward, China's domestic consumption will be driven more by quality than by quantity. That is, whereas people used to be more concerned about whether a product they desired was available in the market, they are now more concerned about whether a product they want meets their quality expectations. They are raising their expectations - a shift that will bring with it untold opportunities for innovation and also for the economy as a whole. Three consumer-related and demographic trends are poised to accelerate consumer demand in China.

First, income growth can lead to consumption growth. According to a 2019 report from the China Society of Macroeconomics (CSM), the annual per capita income in 2018 for 350 million people in China was about USD 25,000; annual income for the remaining 1,050 million Chinese people averaged about USD 4,000. ${ }^{5}$ The number of higher-income earners in China is almost as large as the United States' entire population. If China can maintain the current proportion of the high-income group and gradually increase the income of the low-income group, the country's consumption will have huge potential.

Second, urbanization is expanding domestic demand. China's urbanization rate will be $65 \%$ by $2025,{ }^{6}$ compared to average rates in developed countries of over $80 \%$. This suggests there are still a lot of opportunities for China to tap into a growing

\footnotetext{
${ }^{3}$ Accenture, Innovative China 2030: Break the limits.

${ }^{4}$ http://www.china.org.cn/business/2021-01/29/content_77166788.htm.

${ }^{5}$ http://www.macrochina.com.cn/zhtg/20190218115739.shtml.

${ }^{6}$ http://www.china.com.cn/lianghui/news/2021-03/05/content_77274844.shtml.
} 
urban consumer base. Thanks to digital technologies and advances in logistics, the enormous potential of the country's Tier- 3 and Tier- 4 markets is gradually being released, and a rapid growth rate is expected to be maintained.

Third, the Chinese consumer market exhibits marked generational characteristics that impact demand. Unlike their predecessors, Millennials and Generation Z consumers are more willing to buy new things. They also have a clearer understanding of what they need and want. As these two segments of the population are emerging as a strong force in the consumer market, their idiosyncratic preferences constitute a driving force for the development of new brands. New technologies will also play a role in building demand. While facilitating the development of innovative business models and changing the industrial landscape, digital technologies are also transforming consumer experiences.

\section{Digital Technologies: Boosting Productivity and Innovation Across the Board}

China maintains a competitive edge in the development of a digital economy. The digital technologies that enable consumers' online and mobile interactions have become one of the key drivers of the Chinese economy. According to "Digital Economy Development in China,"7 a white paper prepared by the China Academy of Information and Communications Technology (CAICT), the digital economy accounts for over a third of China's GDP. In the next 30 years, digital technologies are expected to contribute significantly to corporate productivity, permeating industries that account for up to two-thirds or three-fourths of the national economy. Chinese companies recognize that virtually every industry has the potential to unlock significant value through intelligent manufacturing, digital twins, the industrial Internet, Artificial Intelligence (AI) or other digital technologies.

Digital transformation is steadily gaining steam. Since 2018, Accenture has published an annual digital transformation index ${ }^{8}$ that Chinese enterprises can use to understand and track the evolution of that transformation. This research shows that the proportion of leading enterprises seeing notable performance improvements because of digital transformation has increased from $7 \%$ in 2018 to $11 \%$ currently. These organizations differ from other leaders not only in their digital capabilities but also in the ways they approach digital transformation. They emphasize using digital technologies to break through internal barriers and enabling connections across a whole range of business processes. At the same time, they create additional value by using digital technologies to strengthen end-to-end value chain integration, including with external ecosystem partners.

The State-Owned Assets Supervision and Administration Commission of the State Council (SASAC) is promoting digital transformation in state-owned enterprises, as

\footnotetext{
${ }^{7}$ http://www.caict.ac.cn/kxyj/qwfb/bps/202007/P020200703318256637020.pdf.

${ }^{8} \mathrm{https} / / /$ www.accenture.com/cn-zh/insights/consulting/china-digital-maturity-index.
} 
well. SASAC helps them accurately recognize and effectively respond to changes in the digital economy and also encourages them to carry out successful digital transformations in their own organizations. ${ }^{9}$

We are optimistic that digital transformations will continue to accelerate across Chinese enterprises, pushing productivity and innovation to new heights. Technological innovation is already quickly becoming a core competitive advantage and a critical enabler of future industrial performance improvements.

\section{Carbon Neutrality and the Circular Economy: Becoming a More Responsible Environmental Steward}

In 2020, five years after signing the Paris Agreement, Chinese leaders pledged that China would experience peak $\mathrm{CO}_{2}$ emissions before 2030 and reach carbon neutrality before 2060. ${ }^{10}$ To achieve these ambitious goals, the country is looking to scale up its share of non-fossil fuel sources in the energy mix to $25 \%$ by 2030 and also create an installed capacity of wind and solar power totaling 1.2 billion kilowatts. ${ }^{11}$ In its 14th Five-Year Program, published in March 2021, China has vowed to decrease its energy consumption per unit of GDP by $13.5 \%$ and carbon emissions by $18 \% .^{12}$

A recent Accenture white paper, ${ }^{13}$ drafted in conjunction with World Economic Forum, points out that China has reached a critical juncture in its energy transformation. Specifically, China is using digital technologies-including automation, platforms, security, mobility, robotics, data analytics and more-to carry forth is structural upgrades and drive innovations that are enabling the transition of renewable resources to complex, comprehensive energy systems.

China is accelerating the development of an industrial system for a green economy and advocating low-carbon, green ways of living and consuming. At the same time, the country is focusing on digital transformation as an engine for technological innovation and the upgrading of modern manufacturing and service industries. Its emphasis on the production of quality goods means pivoting to production models that are green and sustainable. These are wise moves.

\footnotetext{
${ }^{9}$ http://news.idcquan.com/news/184483.shtml.

${ }^{10} \mathrm{http}: / /$ news.youth.cn/sz/202009/t20200923_12505595.htm.

${ }^{11} \mathrm{http}: / /$ www.qstheory.cn/yaowen/2020-12/13/c_1126854050.htm.

${ }^{12} \mathrm{https} / / /$ www.bjnews.com.cn/detail/161491575015289.html.

${ }^{13} \mathrm{https}: / /$ www.accenture.com/cn-zh/insights/consulting/wef-system-value-china-market-analysis2020.
} 


\section{Entrepreneurship and Innovation: Driving High-Quality Development}

Innovation has consistently been a central priority for Chinese enterprises, which are continuously enhancing their technological innovation capabilities, and also unlocking the innovation potential of their people. These actions will help ensure sustained momentum for long-term economic growth.

Among the global top 10 companies in terms of market capitalization, seven are technology companies, including China's Alibaba and Tencent. ${ }^{14}$ As technological innovation becomes an increasingly important enabler of economic growth, the number of entrepreneurial enterprises is rising. China is home to $22 \%$ of the world's unicorns. According to a recent Accenture study, more than half of the unicorn firms represent $\mathrm{AI}$, information technology and other innovation-driven sectors, and $10 \%$ of them have each generated revenue of RMB 10 billion or more. ${ }^{15}$ Most ( $80 \%$ ) of China's unicorn companies consider technology and innovation as the core capabilities of success and will continue to strengthen their competitiveness in this regard. ${ }^{16}$

Additionally, China ranks 14th in the 2020 Global Innovation Index (GII) Report published by the World Intellectual Property Organization. The country is home to 17 world-class high-tech clusters. Of these, the Shenzhen-Hong Kong-Guangzhou cluster ranks second among those of its kind, surpassed only by the Tokyo-Yokohama cluster. The Beijing cluster ranks fourth. ${ }^{17}$

Clearly, China is taking its commitment to innovation very seriously. And for good reason: Innovation is a critical priority for structural economic growth in the new era. Technological self-reliance features prominently in China's modernization program and will provide the strategic foundation for the country's long-term socioeconomic development. In the 14th Five-Year Program, China estimates its annual R\&D investments will grow by $7 \%$ annually. ${ }^{18}$

China has made tremendous progress in embracing technological innovation, yet there is much left to do. Without a doubt, digital technologies will play an increasingly important role in facilitating international trade and cooperation, stimulating consumption, improving productivity, achieving sustainable growth and unlocking innovation. With a presence in Greater China dating back more than 30 years, Accenture has become a partner of choice for many Chinese enterprises looking to pursue digital transformation. We provide our clients with a suite of services that encompass strategy and consulting, interactive, technology and intelligent operations. We suggest that enterprise leaders seize all possible opportunities for growth in the period of the coronavirus and thereafter.

\footnotetext{
${ }^{14} \mathrm{https}: / /$ www.statista.com/statistics/263264/top-companies-in-the-world-by-market-capitaliz ation/.

${ }^{15}$ Accenture: China Unicorns Survey.

${ }^{16}$ Accenture: China Unicorns Survey.

${ }^{17} \mathrm{https} / / /$ www.wipo.int/edocs/pubdocs/en/wipo_pub_gii_2020/cn.pdf.

${ }^{18} \mathrm{http}: / /$ www.china.com.cn/lianghui/news/2021-03/05/content_77274615.shtml.
} 
The future, of course, is fraught with uncertainties. Other black swan events are likely to occur. At present, however, China has the opportunity to forge ahead and join the ranks of high-income countries. Opportunities can, in fact, emerge from crises, and a more certain future can materialize after a period of uncertainty. We believe there are many reasons to be confident in China's future.

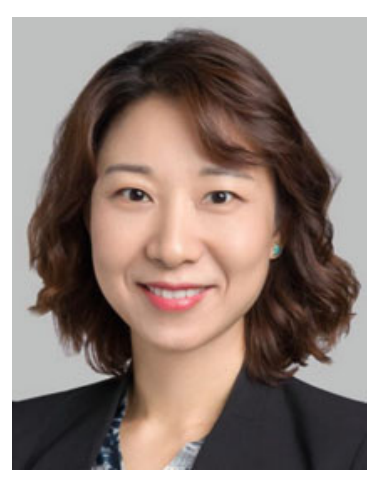

Samantha Zhu is Accenture's Chairperson and Market Unit Lead for Greater China. She leads a team of 18,000 professionals that offer Strategy and Consulting, Interactive, Technology and Operations services to a wide variety of clients. She is also a member of Accenture's Global Management Committee.

Open Access This chapter is licensed under the terms of the Creative Commons AttributionNonCommercial-NoDerivatives 4.0 International License (http://creativecommons.org/licenses/bync-nd/4.0/), which permits any noncommercial use, sharing, distribution and reproduction in any medium or format, as long as you give appropriate credit to the original author(s) and the source, provide a link to the Creative Commons license and indicate if you modified the licensed material. You do not have permission under this license to share adapted material derived from this chapter or parts of it.

The images or other third party material in this chapter are included in the chapter's Creative Commons license, unless indicated otherwise in a credit line to the material. If material is not included in the chapter's Creative Commons license and your intended use is not permitted by statutory regulation or exceeds the permitted use, you will need to obtain permission directly from the copyright holder.

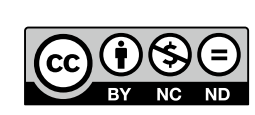

